J. Clin. Chem. Clin. Biochem.

Vol. 19,1981 , pp. $35-38$

\title{
Correlation between Fluorimetric and Microbiological Methods for Determination of Cephalexin in Urine and Serum
}

By F. Plavšic, B. Vrhovac,

Section of Clinical Pharmacology, Department of Medicine, Medical School, Clinical Hospital Centre, Zagreb (Yugoslavia),

\author{
A. Radošević and I. Dvoržak \\ Institute for the Control of Drugs, Zagreb (Yugoslavia)
}

(Received January $2 /$ July $17 /$ September 12,1980 )

Summary: The fluorimetric and microbiological methods for the determination of serum and urine cephalexin were compared with the aid of coded samples in two different laboratories.

The coefficient of correlation between the two methods for serum cephalexin was 0.94 .

At urine cephalexin concentrations above $0.5 \mathrm{~g} / \mathrm{l}$, the coefficient of correlation between two methods was 0.83 .

At lower concentrations $(0.5 \mathrm{~g} / \mathrm{l})$, the coefficient of correlation was 0.72 .

It was concluded that the tested methods are comparable, equally sensitive and precise.

Korrelation zwischen fluorimetrischer und mikrobiologischer Bestimmungsmethode für Cephalexin in Serum und Harn

Zusammenfassung: Die fluorimetrische und mikrobiologische Bestimmungsmethode für Cephalexin in Serum und Harn wurde mit Proben bekannter Konzentration in zwei verschiedenen Laboratorien verglichen. Der Korrelationskoeffizient für die Cephalexinbestimmung in Serum betrug $\mathrm{r}=0,94$. Für Cephalexinkonzentrationen im Harn über $0,5 \mathrm{~g} / \mathrm{l}$ betrug der Korrelationskoeffizient $\mathrm{r}=0,83$, für Konzentrationen darunter $\mathrm{r}=0,72$. Die geprüften Methoden sind vergleichbar, gleich empfindlich und präzise.

\section{Introduction}

Cephalexin is a very useful antibiotic which is present in many countries in oral formulations. The pharmacokinetics of cephalexin and the bioavailability of its oral preparations have therefore been the subject of various studies (1-5).

The analytical methods for cephalexin determination in biological fluids follow the development in analytical methodology. So far, microbiological (6-10), spectroscopic $(11,12)$, fluorimetric $(13,14)$ and high pressure liquid chromatographic $(15,16)$ methods have been described. An evaluation of these methods is difficult from the existing data in the literature.

We therefore evaluated the fluorimetric and microbiological methods by determination of serum and urine cephalexin levels with both methods on the same samples.

\author{
Material and Methods \\ Two different laboratories determined cephalexin concentrations \\ in coded samples of urine and serum. \\ Fluorimetric method. \\ The fluorimetric measurements were performed on a Perkin \\ Elmer fluorimeter M 850 . \\ All chemicals were of analytical grade purchased from "Kemika", \\ Zagreb.

\section{Procedure} \\ $0.6 \mathrm{~mol} / \mathrm{l}$ Trifluoracetic acid $(1 \mathrm{ml})$ was added to serum or stand- \\ ard $(1 \mathrm{ml})$ in a centrifuge tube and the content was vortexed for \\ $5 \mathrm{~s}$ and centrifuged for $5 \mathrm{~min}$ at $4000 \mathrm{rev} / \mathrm{min}$. The supernatant \\ ( $1 \mathrm{ml}$ ) was transferred to a clean glass tube which contained \\ $2 \mathrm{~mol} / 1 \mathrm{NaOH}(0.5 \mathrm{ml})$. The mixture was incubated for $10 \mathrm{~min}$ \\ at room temperature and $2 \mathrm{~mol} / \mathrm{l}$ hydrochloric acid $(0.5 \mathrm{ml})$ and \\ $70 \mu \mathrm{mol} / \mathrm{l}$ solution of $\mathrm{HgCl}_{2}(0.5 \mathrm{ml})$ was added and the tube \\ was incubated for 5 min at room temperature. A $0.9 \mathrm{~mol} / \mathrm{l}$ \\ formaldehyde solution in McIlvaine's citrate-phosphate buffer
}


$\mathrm{pH} 6.5(3.0 \mathrm{ml})$ was added and the tube was incubated $45 \mathrm{~min}$ at $37^{\circ} \mathrm{C}$. The fluorescence of the cooled reaction mixture was measured at $425 \mathrm{~nm}$ with excitation at $345 \mathrm{~nm}$.

\section{Fluorimetric method for urine cephalexin determination}

For concentrations between 0.2 and $5 \mathrm{~g} / \mathrm{l}$ :

Urine $(0.1 \mathrm{ml})$ was added to a glass tube which contained distilled water $(10 \mathrm{ml})$ and it was vortexed for a few seconds. The diluted sample $(1 \mathrm{ml})$ was transferred to a clean glass tube and the $2 \mathrm{~mol} / \mathrm{l}$ sodium hydroxide solution $(0.5 \mathrm{ml})$ was added. The further procedure was identical to the serum method.

For concentrations between 0 and $200 \mathrm{mg} / \mathrm{l}$ :

The sample was diluted with water in a ratio $1: 10$.

Microbiological method

\section{Materials}

"Oxford" Sampler Micropipetting System, 300 1; Nutrient agar medium, prepared as direct in Code of Federal Regulations, Food and Drug Administration, 1973 \& 141.103. Culture media (b) 1. -corresponds to Medium A, BP, 73.

A suspension of the organism, Sarcina lutea ATCC 9341, was prepared as directed in CFR, FDA, 1973. \& 141.104.

\section{Serum level determination}

The stock solution of cephalexin working standard was prepared with phosphate buffer $\mathrm{pH} 6$. This solution was further diluted to the concentrations ranging from $0.2-0.4 \mathrm{mg} / \mathrm{l}$, using a mixture of a pooled human serum and the phosphate buffer in a ratio corresponding to the sample dilution. Each serum sample was diluted with the phosphate buffer to the concentration of cephalexin that is supposed to fall in the range of the standard curve.

The melted nutrient agar medium was inoculated with the test organism suspension that was previously adjusted to a suitable density. The inoculated medium was spilled on large rectangular plates. Holes $12 \mathrm{~mm}$ in diameter were bored in the agar medium. Portions of $300 \mu \mathrm{l}$ each of standard and sample solutions were introduced into the holes. The plates were incubated for 16 to 18 hours at $32-35^{\circ} \mathrm{C}$, and the zone diameters were measured with an accuracy of $0.1 \mathrm{~mm}$. The cephalexin serum level was calculated by means of the data obtained from standard curve.

\section{Urine level determination}

The procedure was the same as described for serum level determination except the standard solution were prepared and diluted in the phosphate buffer. The accuracy of the analysis was tested by adding known amounts of drug to twenty plasma or urine samples at different concentrations. In the microbiological method, reproducibility of results calculated as the standard deviation of zone diameters for each point of the standard solutions and the samples respectively, was not more than 5.0 (zone diameters were measured in $\mathrm{mm} \times 10$ ).

The intra and interassay coefficients of variation, the regression and correlation coefficients were calculated with the prepared programmes from Hewlett Packard on a Hewlett Packard calculator HP-65.

\section{Results}

The limit of detection in the fluorimetric method was $0.1 \mathrm{mg} / \mathrm{l}$. The standard curve was linear in the range of $0-40 \mathrm{mg} / \mathrm{l}$ for serum, $0-250 \mathrm{mg} / \mathrm{l}$ for ten fold diluted urine and $200-3000 \mathrm{mg} / \mathrm{l}$ for hundred fold diluted urine samples.

Table 1 shows inter- and intra-assay coefficients of variation at different cephalexin concentrations in serum and urine with the fluorimetric method (20 determina- tion of each concentrations). The coefficients of variation are satisfactory in all examined concentration ranges. The intra-assay coefficients of variation in the microbiological method were lower than $5 \%$ in all ranges of the serum or urine cephalexin concentrations. In the microbiological method, the range of linearity of the dose-resonse curve was $0.15-1.2 \mathrm{mg} / \mathrm{l}$ with a limit of detection of $0.03 \mathrm{mg} / 1$.

Figure 1 compares the results of the cephalexin serum level determinations between two methods. The regression is represented by the equation $c_{\text {fluorimetric }}=0.32+$ $+1.06 c_{\text {microbiological }}$. The correlation coefficient between the methods was $0.94, s_{x, y} 3.33, s_{0} 0.39$ and $s_{1} 0.03$. Figure 2 represents the correlation between the results of the urine level determination in the concentration range $0-200 \mathrm{mg} / \mathrm{l}$. The regression between two methods is described by equation:

$c_{\text {fluorimetric }}=11+1.02 c_{\text {microbiological }}$. The correlation coefficient was $0.72, s_{\bar{x}, y} 27.7, s_{0} 4.85$ and $s_{1} 0.13$.

Tab. 1. The inter- and intra-assay coefficients of variation in the fluorimetric method for serum and urine cephalexin determination.

Number of determination in the series: 20 each Number of series: 2 each.

\begin{tabular}{lccc}
\hline $\begin{array}{l}\text { Spiked } \\
\text { samples }\end{array}$ & Concentration & $\begin{array}{l}\text { Intra-assay } \\
\text { CV } \\
(\%)\end{array}$ & $\begin{array}{l}\text { Inter-assay } \\
\text { CV } \\
(\%)\end{array}$ \\
\hline Serum & $(\mathrm{mg} / \mathrm{l})$ & 5.3 & 9.9 \\
& 0.84 & 6.2 & 8.3 \\
& 1.48 & 2.0 & 3.1 \\
& 6.5 & 1.6 & 4.2 \\
Urine & 10.3 & 1.8 & 2.5 \\
& 22.2 & 13.2 & 17.3 \\
& 1.1 & 8.2 & \\
& 30.0 & 5.2 & 7.1 \\
& 120.0 & 7.1 & \\
& 220.0 & 2.5 & 6.7 \\
& 920.0 & 2.2 & 3.7 \\
\hline
\end{tabular}

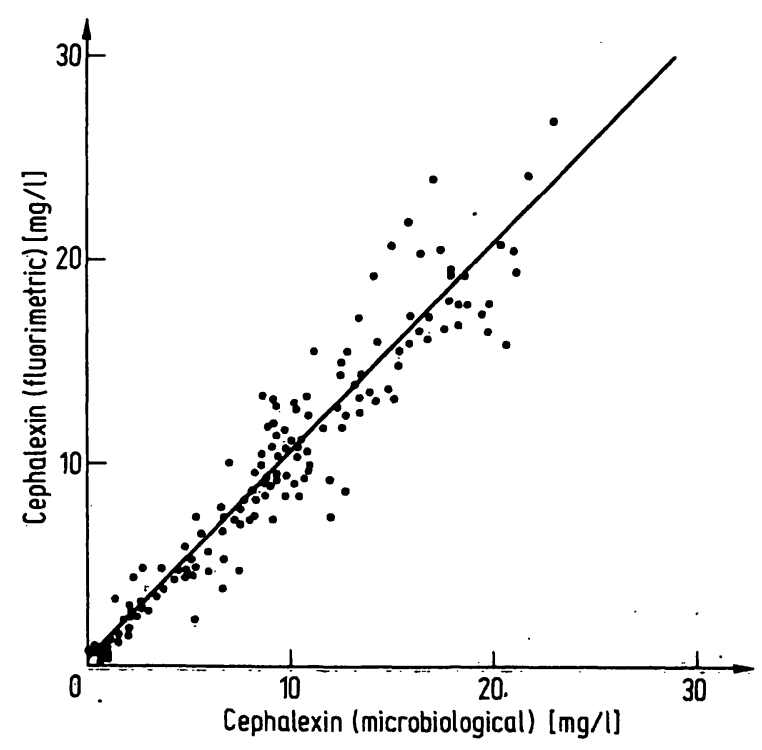

Fig. 1. Correlation between fluorimetric and microbiological methods for serum cephalexin determination. 


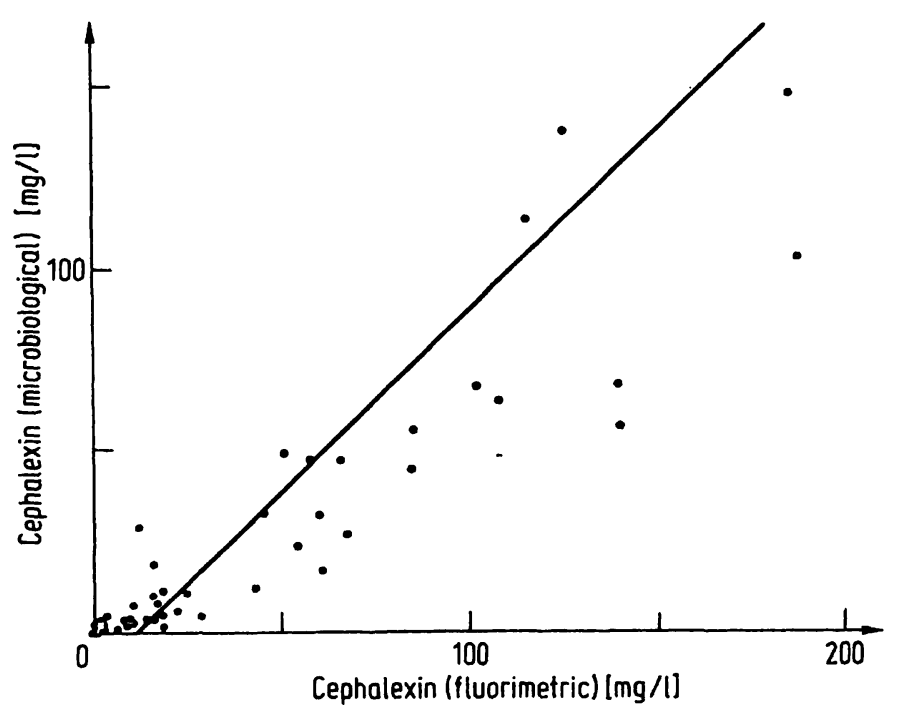

Fig. 2. The correlation between tluorimetric and microbiological methods for urine cephalexin determination at cephalexin concentrations below $200 \mathrm{mg} / \mathrm{l}$.

In figure 3 the results of the cephalexin urine level measurements in the concentration range 200$2500 \mathrm{mg} / \mathrm{l}$ have been compared. The regression is represented with the equation $c_{\text {fluorimetric }}=170+$ $1.06 c_{\text {microbiological }}$. The coefficient of correlation was $0.83, s_{x, y} 413.9, s_{0} 240$ and $s_{1} 0.19$.

\section{Discussion}

The microbiological method (6-10) for cephalexin determination in biological fluids is the most widely used and useful. Fluorimetry is a relatively recent method (14) for cephalexin. This method is based on the measurements of pyrrolidone products of cephalexin rearrangement. The $\beta$-lactam ring is cleaved with sodium hydroxide. Reaction with formaldehyde produces a phenylglycine group which cyclises with the $\beta$-lactam carboxyl to form the pyrrolidone ring. In a report from Barbhayia (14) the cyclisation is catalysed by mercury ions. The reaction recovery is dependent on reaction $\mathrm{pH}$ and on the penicillin or cephalosporin structure.

The fluorimetric method is specific only for substances with an $\alpha$-amino group in the $\mathrm{N}$-terminal position in

\section{References}

1. Grower, P. E. \& Dach, C. H. (1969), Br. J. Pharmacol. 37, 738-740.

2. Griffith, R. S. \& Black, H. R. (1971), Postgrad. Med. J. Suppl. 47, 32-43.

3. Nightingale, C. M., Greene, D. S. \& Quintiliani, R. (1975), J. Pharm. Sci. 64, 1899-1903.

4. Speight, T. M., Brogden, R. N. \& Avery, G. S. (1972), Drugs 3,9-78.

5. Proceedings of a Conference Held at Brighorn, May 11 to 13 (1979), Postgrad. Med. J. Supplement 46, 1-159.

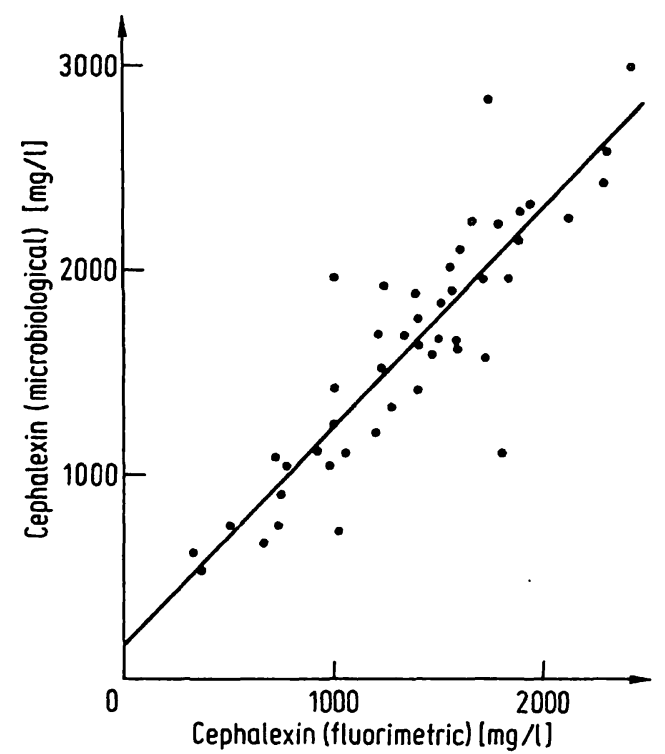

Fig. 3. The correlation between fluorimetric and microbiological methods for urine cephalexin determination at cephalexin concentrations over $200 \mathrm{mg} / \mathrm{l}$.

penicillins and cephalosporins. Therefore only substances with an $\alpha$-amino group, with electronic system such phenyl or phenoxy, and with the possibility of the cyclisation to the pyrrolidone ring may interfere with this method. Cephalexin is not metabolised in man (3). The inter- and intra-assay coefficients of variation are satisfactory in both methods for serum and for urine.

The sensitivity and accuracy are similar in the examined methods. The correlation between two methods for serum cephalexin is very good. It is very important to note that in urine excreted in the first 6 hours the concentrations are higher than $500 \mathrm{mg} / \mathrm{l}$. In this concentration range, the correlation between the two methods for urine cephalexin determination is good.

The methods are comparable in the normal range of cephalexin concentrations and similar in sensitivity and accuracy. The results obtained with the fluorimetric method are slightly higher.

The value of the two methods will not be discussed here with respect to the differences in the pharmacokinetic of cephalexin; the bioavailability calculations for cephalexin preparations will be presented in another paper.

6. O'Calaghan, S. H. \& Kyrbi, S. N. (1978), In Laboratory methods in antimicrobial chemotherapy (Reeves, D. S., Phyllips, I. \& Williams, J. D. eds.), Churchill Livingstone, Edinburg-London-New York, p. 181-193.

7. Bennett, J. W., Brodie, J. L., Benner, E. J. \& Kirby, N. M. M. (1966), Appl. Microbiol. 14, 170-175.

8. Simon, H. J. \& Yin, E. J. (1970), Appl. Microbiol. 14, 573-574.

9. Smith, S. A. \& Smith, S. E. (1973), Br. J. Clin. Pharmac. 3, $341-342$. 
10. Kavanagh, F. (1973), Analytical Microbiology, Academic Press, New York, London, p. 265-270.

11. Alicino, J. (1976), J. Pharm. Sci. 65, 300-302.

12. Mays, D. L., Bangert, F. K., Contrel, W. C. \& Evans, W. G. (1975), Anal. Chem. 47, 2229-2231.

13. Barbhaiya, R. H. \& Turner, P. (1976), J. Pharm. Pharmac. $28,791-793$.
14. Barbhaiya, R. H. \& Tumèr, P. (1977), Br. J. Clin. Pharmac. 4, 427-428.

15. Wald, J. S. (1977), Antimicr. Agents Chemother. 11, 105107.

16. Nakagawa, T., Haginaka, J., Yamamoka, K. \& Uno, T. (1978), J. Chromatogr. 147, 509-511.

Franjo Plavšić

Dept. of Medicine

Section of Clinical Pharmacology

University Hospital Rebro

Kišpatićeva 12

YU-41 000 Zagreb

Yugoslavia 